\title{
Podcasts: Media to Increase Student Learning Motivation
}

\begin{abstract}
Nisrina Nurul Insani*
Universitas Pendidikan Indonesia, Bandung, Indonesia

${ }^{*}$ Corresponding author. Email: nisrina.n.i@upi.edu

ABSTRACT

Students in learning experience obstacles in carrying out their rights and obligations due to the Coronavirus Disease (COVID-19) pandemic. Online learning set by the government as an educational emergency actually has another impact in the learning process. Students have difficulty carrying out online learning, due to monotonous online learning activities, lack of available teaching materials, and learning tools that do not support the learning process. Therefore, it takes creativity of lecturers in developing the online learning process in accordance with the situation and conditions of students so that the learning objectives can still be achieved properly. Case study methods are conducted to find information data on learning media that can help students' difficulties in the online learning process. The data of this study was obtained from the results of interview students, observations of learning, and field notes records. The findings show that varied and innovative learning media can be used as a learning resource and make the learning process interesting. Audio learning media that is podcast can be a solution to increase students' learning motivation in online learning.
\end{abstract}

Keywords: Podcasts; Learning Media; Learning Motivation, Student.

\section{INTRODUCTION}

Today's situation, education and learning face very difficult challenges. Lecturers experience obstacles in carrying out their duties professionally due to the impact of thepandemic Coronavirus Disease (COVID19). The Minister of Education and Culture issued Circular Letter Number 4 of 2020 concerning the Implementation of Educational Policies in the Emergency Period for the Spread of Coronavirus Disease (COVID-19) stating that the learning process is carried out from home through online/distance learning [1]. Education and learning that was previously carried out face-to-face in class has turned into online learning using the internet and online learning application platforms. Of course, this makes the goals of education and learning less attainable.

Online learning has its own advantages and disadvantages. The advantage of online learning is that it is not limited to time and place of learning, giving students the freedom to choose the right time in learning based on their interests, so that the ability to absorb learning materials is higher than learning in class [2]. However, online learning also has several weaknesses, including that students are not properly supervised during the online learning process. Weak internet signal and high quota fees are challenges for online learning [3]. Therefore, it takes the role of lecturers who can make the learning atmosphere more active, innovative, creative, effective, and not boring, which will be able to improve student achievement and motivation to learn better.

The reality is that based on the results of a questionnaire regarding the evaluation of online learning that has been filled out by 150 civic education student respondents, it is known that students have difficulty implementing online learning. $70 \%$ stated that the difficulties that students face in online learning are because online learning activities are monotonous. $30.7 \%$, i.e. 46 students, think that the lack of available teaching materials also makes the learning process difficult. In addition, students also mentioned other factors that made it difficult for them to learn, namely the lack of support for learning devices such as unstable internet, broken laptops, and expensive quota fees, less interactive online learning activities, and suboptimal learning content. This shows that the quality of learning services is starting to decrease and must be improved again.

Improving the quality of educational services that can be done by lecturers is to develop innovative and creative learning processes in the implementation of online learning. The innovation that can be done is to first understand the characteristics of students in online learning and create learning activities that are in accordance with their characteristics. Students prefer the semi-two-way communication model. The semi-twoway communication model can take advantage of chatroom media such as whatsapp. This communication 
model is in demand by many students because students already understand and are accustomed to using chatrooms in their daily activities. Students prefer lecture materials that are distributed in visual form such as softcopy of pdf or power point files, writings, and photos of lecture materials that must be learned from lecturers [4]. Therefore, optimizing online learning requires varied and interactive learning content. Variative and interactive learning content that can be developed by lecturers in the learning process is podcasts.

\section{THEORETICAL REVIEW}

\subsection{Podcast}

Podcast is an application that is widely used today as a means of communication and information. By listening to podcasts, one can know things easily across time and space. Podcasts as learning media can help students find out the description of the material more easily and quickly, so that students are more ready to discuss discussing learning materials. Podcasts can also be a means to get to know the academic environment on campus. Students can hear inspirational stories from various experts so that students are more motivated in lectures and develop their abilities [5]. Podcasts can be a source of innovative and inspiring teaching both inside and outside the classroom. Podcasts bring great benefits especially in today's distance learning era [6]. Podcasts are useful as additional learning media for students, in addition to face-to-face lectures in class with discussions and reading textbooks. Students can better understand concepts, theories and applications that may be missed during face-to-face learning [7]. Podcasts as learning media can also be used as an effort to teach students so that learning objectives can be achieved, so that learning outcomes and student motivation will increase. Podcasts as learning media contain various topics of learning material in the form of conversations, debates or discussions, talk shows, monologues, speeches, and lectures [8].

\subsection{Learning Motivation}

Motivation is a force that can lead to a willingness to carry out an activity. The power of motivation possessed by an individual will determine the quality of behavior he displays in his life. Likewise with the learning process activities, the learning process will be successful if students have high motivation in learning [9]. There are two types of motivation in learning, namely intrinsic motivation and extrinsic motivation. Intrinsic motivation is motivation that comes from within students and extrinsic motivation comes from outside such as the environment and family. Both play an important role in increasing the spirit of learning [10]. The obstacles encountered by teachers in providing learning motivation are related to aspects of students' parents, learning facilities, and inadequate teacher creativity [11]. Therefore, support from various parties is needed to increase student learning motivation.
The teacher acts as a motivator, should provide extrinsic motivation to students, the teacher does not only provide in the form of rewards and punishments but can develop other forms of extrinsic motivation. Teachers must also be able to choose appropriate learning strategies and models by increasing creativity in combining more than one learning model or strategy so as to produce new innovations [12]. Parents act as motivators. The attention of parents is manifested in the form of providing guidance and advice, supervision of learning, giving motivation and rewards, as well as fulfilling learning facilities. Giving guidance and advice makes children have ideals, providing supervision of their learning is to train children to have discipline, giving motivation and rewards so that children are encouraged to learn and excel, while the fulfillment of the facilities needed in learning is so that children are more firm in their stance on an idealism that they want to achieve. achieved by utilizing existing facilities [13].

\section{METHODS}

This study uses a qualitative approach with a case study method. The research was conducted at the Indonesian Pendidikam University, a civics education study program in the odd semester of the 2020/2021 academic year. The research respondents were 100 students who contracted the Introduction to Social Sciences course. The data collection techniques used were student interviews, online learning process observations, and field notes. The data obtained were then analyzed by means of data reduction, data display, decision making and verification.

\section{RESULTS AND DISCUSSION}

Students' learning motivation can be increased by one of the teachers or lecturers increasing their creativity in teaching using renewable media. One of the media that is gaining popularity is podcasts. Podcasts are digital sounds built into the app so they are easy to save and play at any time. Podcasts as learning media can be used to repeat material and improve understanding [5]. One of the greatest pedagogic characteristics that educational podcasting provides is the opportunity to learn through listening [6]. With the use of podcasts in the learning process, it is hoped that students can have more motivation in learning.

Online learning content in the form of podcasts has been tried to be applied to one of the courses, namely Introduction to Social Sciences in the Citizenship Education Study Program, Universitas Pendidikan Indonesia. 100 students who have contracted the Introduction to Social Science course, for approximately one semester learn to use a variety of interactive learning content, one of which is podcasts. Podcasts contain explanations of learning materials that have met several criteria for online learning content so that learning objectives can still be achieved. The results of student 
evaluations of the use of podcasts in the learning process can be found in several assessments and suggestions.

An explanation of the introduction and purpose of the podcast is important. The explanation is a means of information for students to find out where the learning material will be carried out. In addition, easy-tounderstand material can certainly have an impact on increasing student understanding in understanding the material. Material that is easy to understand can also have an impact on increasing the actualization of material by students. The use of communicative language is one aspect of the "podcast" learning media content that needs attention. Communicative language can make students better understand the material in the podcast. As many as $61.3 \%$ of students stated that the communicative language used in the online learning media content "podcast" that was available in the Introduction to Social Sciences Course was fairly good.

$$
75 \text { responses }
$$

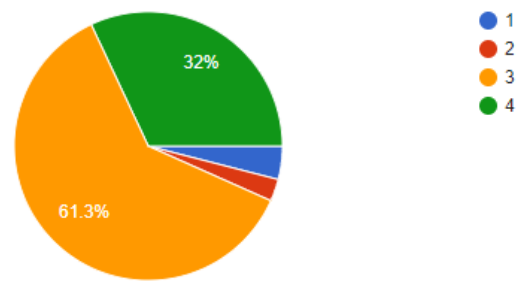

Figure 1. Percentage Diagram of Language Assessment Used in "Podcast" Online Learning Media Content Available in Introductory Social Science Courses

The closing is one of the structural series of the podcast. The existence of a cover in a podcast needs to be a sign that the material that has been delivered on a podcast has ended. Podcast sound quality is one element that needs to be considered. Clear sound on podcasts can make listeners comfortable to listen to podcasts. Therefore, in podcast learning media, it is necessary to pay attention to sound quality so that students become comfortable to receive material through listening to podcasts. In addition, making podcasts must also pay attention to the tone of speech. The tone of speech that is manipulated in such a way, will be able to attract the attention of listeners as quickly as possible, because the duration of the podcast is relatively short. The ways that can be done are to sharpen the speech with the clearest possible articulation, fast, and delivered with high optimism. The presenter takes as little as possible pauses and uses one breath to convey information densely. The principle is to be able to convey as much information as possible with a minimum of time [14]. Then, the use of background music is one aspect that can be added in podcast learning media. Using background music in a podcast can make the podcast feel more alive. As for the use of backsound in podcasts, it is necessary to pay attention to the suitability of the material and not to disturb the sound of delivering the core material.
To make it easier for students to manage podcasts that will be created, students can use theplatforms available. In addition, in order to access podcast content, podcasts are uploaded to various platforms. There are several platforms where to manage and uploadcontent for podcast online learning media for Introduction to Social Sciences, including anchor.fm and spotify. As many as $49.3 \%$ of students stated that thecontent podcast of online learning media for the Introduction to Social Sciences was very good because it had been hosted and stored on platforms such as anchor fm or spotify.

75 responses
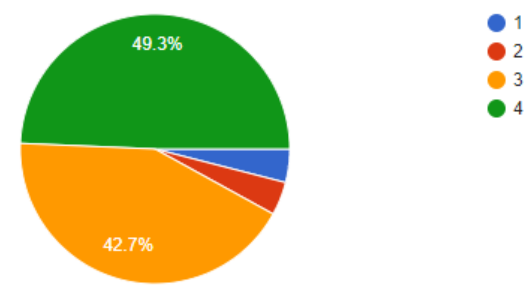

Figure 2. Percentage Diagram of Student Assessment of the Use of Platforms Used in Online Learning Media Content "Podcast" on Introductory Social Science Course

Most students think that the podcasts used are very good and easy to understand. There are several suggestions from students to increase the effectiveness of the "Podcast" Online Learning Media Content in the Introductory Social Sciences Course. Students think that podcast content should be presented more interactively so that students feel involved in the learning process. In addition, podcast content should also be given examples that are relevant to everyday life so that students can more easily understand the material presented. podcast media that is developed should not only be made to accommodate audio learning, but can also be accompanied by a visual version and assignments to accommodate variations in learning styles [5].

Podcast media in learning makes it easier for students to understand learning material so that learning motivation increases. Learning motivation encourages students to study better, while learning media is an effort to teach students so that learning objectives can be achieved, so that learning outcomes and student motivation will increase [8]. Easy access to listening to podcasts is one of the reasons students prefer to learn because they can easily be one click away from the podcast platform without the hassle of downloading learning materials. The grammar used is simpler with the customized background making the explanation of the material easier to understand and interesting. Without the development of learning content developed by lecturers, students feel bored in learning. Therefore, it takes more effort from the lecturers to make the material follow the development of the media as a learning innovation. 


\section{CONCLUSION}

Improving the quality of educational services that can be done by lecturers is to develop innovative and creative learning processes in the implementation of online learning. Podcast media is one of the lecturers' creativities in learning to make it easier for students to understand the learning material so that learning motivation increases. The planned creation of podcast media, simple, interesting, and easily accessible grammar are the main factors for students to be interested in learning. The suggestions that are expected by students are that the content provided pays more attention to the duration so that the material presented is short, solid, and clear. In addition, podcast content should also be given examples that are relevant to everyday life so that students can more easily understand the material presented.

\section{REFERENCES}

[1] Kemendikbud RI, "Surat Edaran Menteri Pendidikan dan Kebudayaan Nomor 4 Tahun 2020 Tentang Pelaksanaan Kebijakan Pendidikan dalam Masa Darurat Penyebaran Coronavirus Disease (COVID-19)," hukumonline.com, 2020.

[2] E. Kuntarto, "Keefektifan Model Pembelajaran Daring Dalam Perkuliahan Bahasa Indonesia di Perguruan tinggi," J. Indones. Lang. Educ. Lit., 2017.

[3] A. Sadikin and A. Hamidah, "Pembelajaran Daring di Tengah Wabah Covid-19 (Online Learning in the Middle of the Covid-19 Pandemic)," BIODIK J. Ilm. Pendidik. Biol., 2020.

[4] N. H. Zhafira, Y. Ertika, and Chairiyaton, "Persepsi Mahasiswa Terhadap Perkuliahan Daring Sebagai Sarana Pembelajaran Selama Masa Karantina Covid-19," J. Bisnis dan Kaji. Strateg. Manaj., 2020.

[5] D. Mayangsari and D. R. Tiara, "Podcast Sebagai Media Pembelajaran Di Era Milenial," J. Golden Age, vol. 3, no. 02, 2019, doi: 10.29408/goldenage.v3i02.1720.
[6] P. M. Hutabarat, "Pengembangan Podcast sebagai Media Suplemen Pembelajaran Berbasis Digital pada Perguruan Tinggi," J. Sos. Hum. Terap., vol. 2, no. 2, Jan. 2020, doi: 10.7454/jsht.v2i2.85.

[7] R. D. Susilowati, S. Sutama, and N. Faiziyah, "Penerapan Podcast pada Aplikasi Spotify Sebagai Media Pembelajaran Matematika di Tengah Pandemi Covid-19," J. Ris. Pendidik. dan Inov. Pembelajaran Mat., vol. 4, no. 1, 2020, doi: 10.26740/jrpipm.v4n1.p68-78.

[8] A. Suriani, C. Chandra, E. Sukma, and H. Habibi, "Pengaruh Penggunaan Podcast dan Motivasi Belajar terhadap Keterampilan Berbicara pada Siswa di Sekolah Dasar," J. Basicedu, vol. 5, no. 2, 2021, doi: 10.31004/basicedu.v5i2.832.

[9] Suharni; and Purwanti;, "Upaya Meningkatkan Motivasi Belajar Siswa," G-Couns J. Bimbing. dan Konseling, vol. 3, no. 1, 2019, doi: 10.31316/g.couns.v3i1.89.

[10] \& Rista, K. and E. A. Ariyanto, "Pentingnya Pendidikan \& Meningkatkan Motivasi Belajar Anak," J. Karya Pengabdi. Dosen dan Mhs., vol. 01, no. 02, 2018.

[11] A. N. Fadlilah, "Strategi Menghidupkan Motivasi Belajar Anak Usia Dini Selama Pandemi COVID19 melalui Publikasi," J. Obs. J. Pendidik. Anak Usia Dini, vol. 5, no. 1, 2020, doi: 10.31004/obsesi.v5i1.548.

[12] F. Hapsari, L. Desnaranti, and S. Wahyuni, "Peran Guru dalam Memotivasi Belajar Siswa selama Kegiatan Pembelajaran Jarak Jauh," Res. Dev. J. Educ., vol. 7, no. 1, 2021, doi: 10.30998/rdje.v7i1.9254

[13] H. Hero and M. E. Sni, "Peran Orang Tua Dalam Meningkatkan Motivasi Belajar Siswa Kelas V Di Sekolah Dasar Inpres Iligetang," JRPD (Jurnal Ris. Pendidik. Dasar), vol. 1, no. 2, 2018, doi: 10.26618/jrpd.v1i2.1568.

[14] R. Mulyani, "Eksplorasi Terhadap Kemungkinan Desain Podcast Pendidikan Tinggi di Indonesia," Aksara J. Ilmu Pendidik. Nonform., vol. 7, no. 2, 2021, doi: 10.37905/aksara.7.2.381-394.2021. 